BULLETIN Bulletin hispanique

HISPANIQUE Université Michel de Montaigne Bordeaux

$113-2$ | 2011

Varia

\title{
Propuesta de lectura fiscal del Lazarillo de Tormes
}

\section{Susana Camps Perarnau}

\section{OpenEdition}

\section{Journals}

Edición electrónica

URL: http://journals.openedition.org/bulletinhispanique/1435

DOI: 10.4000/bulletinhispanique.1435

ISSN: 1775-3821

\section{Editor}

Presses universitaires de Bordeaux

\section{Edición impresa}

Fecha de publicación: 1 diciembre 2011

Paginación: 663-699

ISBN: 978-2-86781-793-9

ISSN: 0007-4640

\section{Referencia electrónica}

Susana Camps Perarnau, « Propuesta de lectura fiscal del Lazarillo de Tormes », Bulletin hispanique [En línea], 113-2 | 2011, Publicado el 01 diciembre 2014, consultado el 02 mayo 2019. URL : http:// journals.openedition.org/bulletinhispanique/1435; DOI : 10.4000/bulletinhispanique.1435 


\title{
VARIÉTÉS
}

\section{Propuesta de lectura fiscal del Lazarillo de Tormes}

\author{
Susana Camps Perarnau \\ Barcelona - España
}

Les allusions à la réalité économique, dans le Lazarillo, sinscrivent dans une perspective bien définie : celle de la fraude et de l'exemption fiscale, recherchée par le personnage. Cette volonté, aujourd'hui apparemment ignorée mais évidente pour le lecteur de l'époque, confere une dimension inédite à ce texte toujours étonnant.

Las alusiones a la realidad económica del Lazarillo confluyen en un sentido muy bien delimitado: el del fraude y la exención fiscal que procura el mozo. Esta voluntad, aparentemente oculta hoy pero evidente para el lector del momento, aporta una dimensión ignorada a este texto siempre asombroso.

The economic reality that lies behind the Lazarillo marks a very well delimited perspective: that of the fraud and fiscal exemption that the young boy is looking for. This will, seemingly secret today but evident for the reader of the time, endows this amazing text with an original dimension.

Mots clés : Lazarillo - Exemption fiscale - Impôt - Fraude - Service.

Bulletin Hispanique, Tome 113, n 2 - décembre 2011 - p. 663 à 699. 
U N puñado de términos del Lazarillo de Tormes, hábilmente agazapados tras el potente flujo de la historia, desdibuja su pertenencia al ámbito de la economía tras la sombra de ambigüedad que proyecta el paso del tiempo. La tensión narrativa del texto hace que pasen velozmente ante la mirada del lector, pero un análisis detenido permite afirmar que la realidad económica del contexto asoma en certeras pinceladas. El propósito de este estudio es destacarlas y cuestionar su valor, dado que pueden favorecer una lectura significativa y distinta del texto.

Al principio del relato, Lázaro cita el «pan, pedazos de carne y en el invierno leños a que nos calentábamos» ${ }^{1}$ o el «vino y candelas» por el que lo mandaban, siendo muchacho, en el mesón. En términos fiscales integran el concepto comer, beber y arder; una categoría, la de los productos básicos, a la que apenas llegaban los más pobres, y la única a la que Lázaro tiene acceso al principio.

Cuando Lázaro extrae comida del saco del ciego, que descose, consigue sacar "no por tasa pan, más buenos pedazos, torreznos y longaniza", compensándose sobradamente por la estrechez en que lo obligaba a vivir. De nuevo un gravamen.

Poco más adelante aparece la palabra sisa, asociada a hurto por el uso que el mozo hace de las monedas que consigue el ciego: «todo lo que podía sisar y hurtar traía en medias blancas». De este modo, antes de que el ciego alcanzara a recoger el pago de una blanca entera ofrecida por quienes le mandaban rezar, él ya se la había trocado por media, «aniquilada en la mitad del justo precio». La sisa era el modo de pago de un impuesto medieval vigente a lo largo del siglo XVI, que se cobraba restando una parte del producto gravado; cuando Lázaro asocia sisa a hurto indica el uso fraudulento de dicha práctica fiscal contemporánea, y dota al término de su sentido moderno, que ha acabado imponiéndose y desplazando el primitivo.

En el mismo párrafo aparece el término cambio, que como reveló Francisco Rico ${ }^{2}$ encierra una particular aplicación de los usos económicos de la época. El cambio era una práctica habitual en un momento en que los

1. Citaremos a partir de la edición digital de la Biblioteca Virtual Cervantes, basada en las de Burgos, Juan de Junta, 1554; Alcalá de Henares, en casa de Salzedo, 1554; Amberes, en casa de Martín Nucio, 1554 y Medina del Campo, Mateo y Francisco del Canto, 1554; cotejada con las ediciones críticas de Alberto Blecua, Madrid, Castalia, 1972, José M. Caso González, Madrid, BRAE 1967; Anejo XVII y Francisco Rico, Madrid, Cátedra, 1987. [En línea:] <http://www.cervantesvirtual.com/servlet/SirveObras/12482952001249396310068/ p0000001.htm>

2. Francisco Rico, Problemas del Lazarillo. Madrid, Cátedra, 1988, p. 93-112. 
procuradores castellanos denunciaban insistentemente la escasez de moneda pequeña o vellón (ya en las Cortes de 1518, 1520, 1523 y 1525, y también problemas asociados como la introducción de moneda forera y la extracción de sacas, que se prolongarán a lo largo de todo el reinado del emperador). Esta falta de moneda pequeña hacía necesario el cambio, por el que algunos usureros cobraban una comisión abusiva; realidad a la que alude el autor al llamar sarcásticamente cambio al hurto de Lázaro. El profesor Rico rastreó las críticas y consideraciones morales escritas en la época sobre este tipo de usura, demostrando la intención con que se utiliza el término.

Igualmente se sugiere una actividad económica fraudulenta por parte del clérigo: «el ratón y culebra que me daban guerra y me comían mi hacienda he hallado", exclama refiriéndose al pan que oculta bajo llave en época de carestía y con el que, por la precisión del término, se puede entender que especula, pues la primera acepción de hacienda no era patrimonio, sino actividad económica. Así lo definía Covarrubias en 1611, al derivar el término hazienda de «hazer, que es trabajar, porque el que trabaja hace hazienda, y el que la deshaze y consume. Tómase por el caudal y capital que cada uno tiene» ${ }^{3}$. Las referencias y denuncias de la especulación del trigo y el pan son materia frecuente en los cuadernos de Cortes de todo el siglo.

Lázaro expone en el Tratado Sexto, el del capellán, que empieza a prosperar y puede vestir con cuestionable decoro porque «los sábados ganaba para mí». Al final de la obra manifiesta que tiene habilidad y buen vivir, y que «en toda la ciudad, el que ha de echar vino a vender, o algo, si Lázaro de Tormes no entiende en ello, hacen cuenta de no sacar provecho». De nuevo una realidad económica: se ha situado bien porque ha conseguido tener parte en los negocios de compraventa de la ciudad. Tener parte o menguar algo del monto final es el camino que ha elegido para prosperar, como veremos en adelante. Una acción que se presenta concretamente en términos fiscales.

Ya advertía el profesor Rico sobre algunas de sus consideraciones:

Son, diría yo, apreciaciones estrictamente literarias. Pero no olvidemos que no las hemos conseguido gracias a ningún tratado de crítica o de teoría de la literatura, sino con el Comentario resolutorio de cambios y con Carlos Vy sus banqueros ${ }^{4}$.

3. Sebastián de Covarrubias, Tesoro de la lengua castellana o española. Martín de Riquer (ed.). Facsímil. Barcelona, Alta Fulla, 1987, p. 679.

4. Francisco Rico, op. cit., p. 112. 


\section{Algunas Cuestiones SOBRe LA PROSPERIDAd DE LÁZARO}

Queda claro que la historia narrada por el protagonista adopta la forma de un relato iniciático con recorrido lineal y final explicativo del punto de partida $y$, aunque no existe una simetría perfecta que imponga una estructura obvia (sino que, por el contrario, requiere cierto esfuerzo exegético estructurarla), el lector intuye que los amos de Lázaro han de ofrecer algún denominador común, porque forman parte de un proceso gradual y porque los uniformiza el común anonimato.

Lázaro declara, además, que su presente deriva de la enseńanza unívoca de estos amos. Si explica su historia desde el principio «y no por el medio» es precisamente para justificar su estado presente con una línea clara de aprendizaje: "procuré un oficio real, viendo que no hay nadie que medre, si no los que le tienen». El último amo, el arcipreste de San Salvador bajo cuya protección vive, llega incluso a sentenciar que «quien ha de mirar a dichos de malas lenguas nunca medrará», y le aconseja: «no mires a lo que pueden decir, sino a lo que te toca, digo, a tu provecho». A lo que Lázaro le responde: «señor, yo determiné arrimarme a los buenos». Obviamente están hablando de nuevo en términos materiales, de provecho económico. Este es entonces el fin último del relato de los avatares del mozo, a falta de cualquier otro objetivo manifiesto; no le hemos visto «crecer» en ningún otro ámbito personal, sólo en el plano socioeconómico.

Nos mantendremos deliberadamente dentro de un primer nivel de lectura, sin buscar el fin último que motiva al autor a plantear la historia, con la intención de establecer las coordenadas en que se apoya el nivel más básico de la narración: aquel al que podían llegar todos los lectores, también los que no alcanzaban a interpretar posibles alusiones biográficas en la obra. El nivel que permite que «a los que no ahondaren tanto, los deleite».

¿Qué podían tener en común todos los amos de Lázaro para adiestrarle en un progreso socioeconómico del que está manifiestamente orgulloso? Por supuesto, nada técnico: lo que Lázaro ha aprendido de todos ellos no es ninguna de las actividades principales de los núcleos de población que menciona. Dada la actividad preponderante en las ciudades castellanas por las que transita Lázaro5 ${ }^{5}$ es muy notable la ausencia de comerciantes, tejedores,

5. Burgos, Medina del Campo y Toledo se dedicaban principalmente al comercio (a destacar el sector textil -seda y ropavejeros- toledano); Segovia y Cuenca a las manufacturas de pagos y a la ganadería; Salamanca a la agricultura y a la actividad universitaria; Valladolid, sede de la Chancillería, a las tareas jurídicas, burocráticas y administrativas y al artesanado de lujo. Véase Felipe Ruiz Martín, "La población española al comienzo de los tiempos modernos», en Cuadernos de Historia. Anexos de la revista Hispania, 1967 vol. 1, p. 189-202; 
zapateros, boneteros, ceramistas, agricultores, estudiantes (excepto mención fugaz) y profesores en torno al mozo. En el mismo sentido, por ostentosa omisión puede afirmarse que en el Lazarillo «faltan» muchas capas sociales: personajes de la alta nobleza, la alta clerecía, de la oligarquía urbana y de las clases medias (labradores, artesanos, industriales, profesiones liberales); el pueblo llano sólo asoma, superviviente, al fondo.

Por otro lado, se destaca un concepto social que puede servir de indicio. Siendo la madre de Lázaro viuda y extremadamente pobre, «determinó arrimarse a los buenos por ser uno de ellos», y en su madurez el pregonero confirma al arcipreste esta elección: «yo determiné arrimarme a los buenos». ¿Quiénes serán estos «buenos» que constituyen el objetivo y modelo a seguir? Aunque se trate, obviamente, de escapar del estamento más bajo de la sociedad para pasar a un nivel superior, hay varios, como varios son los modos de alcanzarlos, y Lázaro no elige ser criado, labrador o comerciante, sino que busca única y exclusivamente lo que aprende. Mucho se ha hablado del uso y valor de la elipsis en el Lazarillo; la peculiar selección de personajes apunta hacia un objetivo muy concreto precisamente por exclusión de lo más lógico. Por ejemplo, es significativo que, ante la penuria que retrata la obra, el sistema, el emperador o la alta nobleza salgan incólumes de su crítica. Los verdaderos responsables del sufrimiento y de la inmoralidad de Lázaro son aquellos personajes que de un modo u otro viven a costa de los demás y que tienen por objetivo «sacar provecho». Por eso lo que ha aprendido Lázaro es a medrar: sacar provecho o parte, como hacen determinados oficios (los reales), pues «no hay nadie que medre, sino los que le tienen».

En realidad, ellos son el verdadero cáncer del sistema: no les preocupan las necesidades del imperio ni «los cuidados del rey de Francia»; sólo desean medrar. Tal vez se esconda aquí una alusión al contraste existente entre la política exterior y los males internos de Castilla.

\section{DE LOS «HOMBRES BUENOS» A LOS «BUENOS HOMBRES»}

El objetivo de Lázaro, pues, es arrimarse a «los buenos». El uso de la expresión «hombres buenos» en documentos de carácter principalmente jurídico, aunque también en las crónicas y en la literatura, permite deducir que se trata de una categoría o un concepto social, más que moral, aunque originariamente se asociara a la honradez.

Vicente Pérez Moreda, «El crecimiento demográfico español en el siglo XVI.» En Jerónimo Zuritasu época y su escuela. Zaragoza : «Institución Fernando el Católico», 1986, p. 55-71. 
Los «hombres buenos» formaban la capa superior de la sociedad urbana y obtenían consideración, respeto y reconocimiento en los documentos, donde son citados por detrás de hidalgos y escuderos (pues proceden de familias relevantes, aunque no necesariamente con cargos políticos). No formaban parte de la nobleza, sino de un sector destacado del común de los habitantes de un lugar ${ }^{6}$. He aquí algunos ejemplos de un amplio arco cronológico:

Los Reyes Católicos a las autoridades de Vizcaya, Guipuzqua y Laredo, en creencia de García de Cotes, corregidor de Burgos. Concejos, corregidores, alcaldes, regidores, officiales e hombres buenos de las villas e lugares del condado de Vizcaya e prouincia de Guipuzqua, e Laredo, e todas las otras que son en la costa de la mar. Nos embiamos mandar a Garcia de Cotes... ${ }^{7}$.

E por la presente mandamos al Príncipe Don Enrique [...] y al Maestre de Santiago, Condestable de Castilla, é á los Duques, Condes, Marqueses, Caballeros, Ricos hombres, Maestres de las Ordenes, Comendadores, alcaydes de los castillos é casas fuertes, é á los del nuestro Consejo, Oydores de las nuestras audiencias, alcaldes, alguaciles é otras justicias cualesquier de la nuestra casa é Corte é chancillerías, é á todos los consejos, corregidores, alcaldes, alguaciles, regidores, jurados, caballeros, oficiales y hombres buenos que agora son é serán de aquí adelante, é á otras cualesquier personas, nuestros súbditos y naturales, de cualquier estado, condicion, preeminencia ó dignidad que sean, que guarden y cumplan y executen, é fagan guardar cumplir y ejecutar esta nuestra carta de merced é lo en ella contenido ${ }^{8}$.

Este dicho dia el conçejo e hombres buenos de Arguebanes hizieron convenyençia con el prior, monjes e convento de Santo Toribio, que el dicho conçejo, los que agora son e seran de aqui adelante en el dicho logar ayan de guardar e guarden de cada un anno el prado de Soera de la misma forma que guardan el prado de la Prada, y que el prior, monjes e convento les ayan de dar e den tres mill e quinientos maravedis?.

6. Esta definición general nos fue amablemente facilitada por la profesora María Isabel del Val Valdivieso, catedrática de Historia Medieval de la Universidad de Valladolid, con la advertencia de que la complejidad del concepto exigiría mayores matices.

7. Anónimo, 1497, Documentos sobre relaciones internacionales de los Reyes Católicos, II (ed. Antonio de la Torre), Barcelona, CSIC, 1965-1966, V, p. 413.

8. Anónimo, c. 1500, Privilegio de don Juan II, Madrid, Antonio Paz y Melia, M. Tello, 1890, p. 60.

9. Anónimo, 1502, Testimonio del notario Martín Ruiz. Colección diplomática de Santo 
Y por lo semejante, [a] los prelados y personas eclesiásticas amonestamos atentamente, y a los lugarestenientes generales, visorreyes y governadores, príncipes, almirantes, duques, marqueses, condes, vizcondes, y a los de nuestro Consejo y Audiencias, y nuestros oficiales, alcaldes, nobles, varones, mesnaderos, valvasors, cavalleros, infançones, ciudadanos, burgueses, concejos, oficiales y hombres buenos de qualesquier ciudades, villas y lugares de todos los dichos nuestros reinos y señoríos de la Corona de Aragón, [aquende] y allende del mar [...] mandamos [...] tengan la dicha forma de regimiento y governación ${ }^{10}$.

Por nos, Miguel Lopez de Ciordia, e Martin de Gastamiça, e Martin Ruiz de Echeberria, e Johan Sanchez de Ylardi, juezes arbitros, arbitradores, amigos amigables componedores e juezes de adbenencia, tomados y escogidos e nombrados entre partes, combiene a saber, de la vna parte los escuderos hijosdalgo e hombres buenos vezinos e moradores de los lugares, concejos de la tierra e valle de Burunda [...] sobre las diferencias que hauia entre las susodichas partes ${ }^{11}$.

Y después deven dar sus galardones a los que primero entraron en la villa o castillo por fuerça de combate o por hurto, y a los otros después que ganaron aquel lugar; el qual galardón se deve dar al alvedrío de hombres buenos y comunes, catando lo que hizieron y la forma ${ }^{12}$.

En esta vida, todos los estados y oficios de la república son necesarios para sustentación, unos más y otros menos. Al salir della y al paradero, caballeros y escuderos y oficiales y hombres buenos, labradores y señores, hijosdalgos y villanos, todos seremos iguales, et in cinerem reverteremur ${ }^{13}$.

El concepto social y el uso de "hombres buenos» es amplio y difícil de definir; debemos atenernos a la definición de los historiadores. En cualquier

Toribio de Liébana. Elisa Álvarez Llopis; Emma Blanco Campos; José Ángel García de Cortázar (eds.), Santander, Fundación Marcelino Botín, 1994, p. 375.

10. Alonso de Santa Cruz (1491-1516), Crónica de los Reyes Católicos, Juan de Mata Carriazo (ed.), Sevilla, Escuela de Estudios Hispano Americanos, 1951, II, p. 381.

11. Anónimo, 1516, Sentencia de pleito en amojonamiento. Documentación municipal de la cuadrilla de Salvatierra, Felipe Pozuelo Rodríguez (ed.), Donostia, Eusko Ikaskuntza, 2001.

12. Hugo de Celso (1540-1553), Repertorio universal de todas las leyes de estos reinos de Castilla, María Jesús Vidal Muñoz-Mariano Quirós García (eds.), Salamanca, CILUS, 2000.

13. Juan de Arce de Otárola (c. 1550), Coloquios de Palatino y Pinciano, José Luis Ocasar Ariza (ed.), Madrid, Turner, 1995, I, p. 242. 
caso, que Lázaro determine arrimarse a «los buenos» desde su baja cuna y su inexistente honra alerta inmediatamente al lector sobre una meta que parece imposible de alcanzar.

La contraposición entre el objetivo ideal y el real sugiere que tal vez no sean lo mismo «los buenos» de Lázaro que «los hombres buenos» de la ciudad; o que tal vez los «hombres buenos» no lo sean tanto, y el contenido original del enunciado tenga una brecha moral, como la que esconden otros términos de la obra. Irremediablemente resuena la contraposición entre «hombres ricos» y "ricos hombres» de don Juan Manuel, y poco a poco se impone la perversión del adjetivo «buenos», magistralmente guiada por la ironía del autor, que utiliza el adjetivo antepuesto al nombre para calificar a la persona por su bondad, pero pospuesto cuando lo asocia a una casta social de cuestionable catadura moral.

Así, Lázaro es al principio un «buen mozuelo», hijo de «un buen hombre», y el ciego es un «buen amo» $y$ «el bueno de mi ciego»... hasta el primer golpe. Gracias a la ayuda de las «buenas gentes» sobrevive al garrotazo del clérigo, en el Tratado Segundo. En el Tercero, el escudero es «el bueno de mi amo», y «buenas gentes» dan algo de comida a Lázaro para que coman los dos; también «el bueno de mi amo» se ríe a carcajadas del equívoco del muerto. Los «buenos hombres» son aquellos a los que se dirige el buldero al inicio de su plática, en el Tratado Quinto; también quienes suplican cándidamente que socorra al pecador que, fingiéndose castigado por Dios, se retuerce como endemoniado por el suelo; así los llama por segunda vez el buldero, de nuevo en estilo directo, cuando se aviene a obrar su engañoso milagro. Y todavía es Lázaro un «buen mozuelo» en el Tratado Sexto ${ }^{14}$. El uso antepuesto del adjetivo para calificar la bondad se mantiene hasta el final, cuando Lázaro ya forma parte de «los buenos» y conviene con su amo que es preferible medrar.

En el Tratado Séptimo y último es donde se sustantiviza y se distorsiona la verdad: ahora que Lázaro es "uno de los buenos», proclama que su mujer es «buena hija e diligente y servicial» mientras nos deja saber que está amancebada con el arcipreste de San Salvador, y aunque afirma que «es tan buena mujer como vive dentro de las puertas de Toledo", frase elocuente donde las haya. La calificación moral ha descendido al tiempo que se elevaba la condición social del muchacho: ha pasado de "buen mozo» a «uno de los buenos». Una transformación que parece paralela a la que acusa el concepto de honra a lo largo del siglo, y aun en el mismo Lazarillo, donde recordemos

14. Como expresión alternativa, el inequívoco calificativo "hombre de bien», que el escudero emplea hasta tres veces. Lázaro, cuando logra vestirse con ropa usada, alcanza «hábito de hombre de bien» (advierten los estudiosos que con tácita referencia al proverbio el hábito no hace al monje). 
que no es equivalente la honra que defiende el escudero en el Tratado Tercero ( $¡ \mathrm{Oh}$, Señor, y cuántos de aquestos debéis Vos tener por el mundo derramados, que padecen por la negra que llaman honra, lo que por Vos no sufrirán!», se burla el mozo), y la honra que promete el arcipreste («mi señor me ha prometido lo que pienso cumplirá») al muchacho, mucho más próxima al privilegio.

¿Qué tipo de honra está esperando, pues, Lázaro de su amo? Sin duda, no la de los que son honrados, sino la de los que son honrados por los demás. La honra de los que medran.

\section{ENTORNO ECONÓMICO DE LA OBRA: EL REINADO DE CARLOS V}

Ramón Carande glosa, en breves frases, los ejes determinantes de toda una época:

el derrumbamiento de su hacienda [de Castilla] en los días de nuestra hegemonía [...] la falta de un sistema político dirigido al fomento del bienestar nacional y, con ello, el contraste existente entre el dolor humano de los españoles más numerosos y humildes, atosigados bajo la sobrecarga fiscal, y el respeto dispensado a los privilegios de sujetos exentos de la obligación de contribuir ${ }^{15}$.

El problema fiscal es, para los economistas, la clave de la mala gestión administrativa del imperio y la causa última de su derrumbamiento a finales del siglo XVII. Un problema con dos vertientes: la deuda y la presión tributaria. Las desigualdades fiscales habían provocado en gran parte el primer conflicto al que se enfrentaría el emperador a su llegada a Castilla (la guerra de las Comunidades, 1520-1521), y no hallaría solución en sus cuatro décadas de reinado. Escribía fray Antonio de Guevara en 1521:

También, señor, os dixe que me parescía gran vanidad y no pequeńa liviandad lo que se platicava en aquella junta, y lo que pedían los plebeyos de la república, es a saber, que en Castilla todos contribuyesen, todos fuesen iguales, todos pechasen y que a maneras de señorías de Italia se gobernasen, lo qual es escándalo oirlo y blasfemia decirlo, porque así como es imposible governarse el cuerpo sin brazos, así es imposible sustentarse Castilla sin caballeros ${ }^{16}$.

15. Ramón Carande, Estudios de historia, Barcelona, Crítica, 1989, vol. I, p. 86.

16. Antonio de Guevara, Epistolas familiares. Obras completas de fray Antonio de Guevara, Madrid, Fundación José Antonio de Castro, 2004, vol. 3. Carta a Juan de Padilla, fechada en 
Gran cantidad de testimonios confirman que el factor fiscal fue el principal detonante de la guerra castellana y demuestran la precariedad de la Hacienda desde principios del reinado de Carlos $\mathrm{V}^{17}$. Al problema generado por una deficiente política hacendística arrastrada desde los tiempos de los Reyes Católicos se sumaba la resistencia de los estamentos a perder sus privilegios y a menguar su patrimonio. Pero Carlos de Gante, investido emperador en 1519, no cesó nunca de reclamar fondos para sostener su política imperial. Desde el principio la guerra con Francia, el imperio turco y las rivalidades con otras monarquías requirieron una inversión que las arcas de Castilla a duras penas podían atender a pesar del oro que llegaba de América. Así lo reflejan los libros de Cortes, donde queda el testimonio de las tensiones de la monarquía con los brazos estamentales. La creación de un Consejo de Hacienda en 1523 y sus inmediatas pesquisas no lograron poner orden en un sistema de recaudación y créditos desfasado y, lamentablemente, no mercantilista ${ }^{18}$; Felipe II heredó su mala gestión.

El sistema fiscal de los Austrias resulta complejo incluso para los especialistas que intentan descifrar hoy sus mecanismos y, en estos últimos años, definir figuras determinantes y poco consideradas hasta ahora, como la de los arrendadores de rentas. Sin embargo, intentaremos exponer un esquema básico de funcionamiento para que nuestra hipótesis se inscriba en un marco histórico claro. Adviértase que, naturalmente, no interesa aquí la gestión administrativa de los gastos de la corona ni sus deudas con asentistas y banqueros, sino la fiscalidad aplicada al pueblo.

Las rentas ordinarias, es decir los ingresos que recibía la monarquía, estaban compuestas principal, aunque no únicamente, por los servicios y las alcabalas. El servicio era un impuesto directo e individual, que se calculaba sobre el patrimonio y la renta de cada pechero y de acuerdo con las condiciones de la localidad donde vivía (señorío, realengo o abadengo). Aunque inicialmente era recaudado por los arrendadores de alcabalas, con la creación del Consejo de Hacienda se dispuso la intervención de oficiales de la Contaduría (si bien en la práctica fue gestionado por los Concejos locales). El servicio era una prestación fiscal que el rey solicitaba a los brazos estamentales cada vez que convocaba a cortes, lo que normalmente sucedía cada tres ańos; los

Medina del Campo el 7 de marzo de 1521.

17. David Alonso García, "Dinero en Castilla. Notas sobre el pago de guardas de 1523», en Tiempos Modernos $\mathrm{n}^{\circ}$ 8, mayo-septiembre 2003, p. 6. Alude a la amplia documentación presentada por Joseph Pérez, La revolución de las Comunidades de Castilla (1520-1521), Madrid, 1999, y Manuel Danvila Collado, Historia critica y documentada de las Comunidades de Castilla, Madrid, 1897-1899 (6 vols.).

18. Ramón Carande, op. cit., p. 89. 
especialistas observan que Carlos V adelantaba la convocatoria precisamente por la necesidad que tenía del servicio para sus empresas exteriores, y no por motivos de gobierno.

La alcabala era pagada al completo por el vendedor, aunque en los trueques afectaba a ambos permutantes ${ }^{19}$. Su monto dependía de la fluctuación de los precios; por este motivo los Reyes Católicos habían instaurado el encabezamiento, un cupo derramado sobre los contribuyentes que tenía la función de aligerar el peso de la alcabala ${ }^{20}$. Sin embargo, no todos los municipios se acogían a este sistema, por lo que el régimen era dualista y desigual. El primer encabezamiento general no tuvo lugar hasta 1536; con él Carlos V se aseguraba unos ingresos fijos, que necesitaba con creciente urgencia, y los municipios podían disponer de la sobra o exceso de recaudación para fines locales. Según Ramón Carande,

Entre 1495 y 1536 no tenían encabezado el pago de la alcabala todos los concejos del reino, e imperaba, por consiguiente, un régimen dualista. Eran muchos los municipios donde subsistían los arrendatarios. Conocidas las tretas de estos mal reputados intermediarios, nada tiene de extraño que su gestión resultase odiosa para los contribuyentes. Son, por lo mismo, explicables y verosímiles las reiteradas quejas de las cortes, con resonancia extraordinaria a partir de 1523. El monarca se mostró dispuesto a revisar aquel estado de cosas, y, con su beneplácito, se inicia el período de negociaciones, rematadas el ańo 1536, en el llamado encabezamiento general del reino $^{21}$.

Mediante el encabezamiento general, el rey fijaba un límite en sus ingresos y cedía el exceso a los gobiernos locales. La recaudación estaba en manos de un gran número de agentes particulares que se hacían cargo del arrendamiento después de haber pujado para obtener el cargo de arrendadores en subasta (primero debían demostrar que disponían de patrimonio o crédito suficiente para asegurar los pagos del arrendamiento, lo que la Contaduría comprobaba mediante averiguaciones cuyos documentos se conservan en el archivo de Simancas $)^{22}$. No se trataba de oficiales pertenecientes a la Real Hacienda,

19. Miguel Ángel Ladero Quesada, El siglo XV en Castilla. Fuentes de renta y politica fiscal, Barcelona, Ariel, 1982, p. 47.

20. Miguel Ángel Ladero Quesada, La Hacienda Real de Castilla en el siglo XV, La Laguna, Universidad de La Laguna, 1973.

21. Ramón Carande, op. cit, p. 95.

22. Juan Manuel Carretero Zamora, «Las oligarquías locales y los mecanismos de exención del servicio de Cortes en la época de Carlos V", en Espacio, Tiempo y Forma, Serie IV, Historia Moderna n 11, 1998, p. 11-37. 
sino de intermediarios cuya ganancia radicaba en la diferencia entre lo que se habían comprometido a pagar y lo que efectivamente recaudaban ${ }^{23}$. Estos arrendadores obtenían interesantes contraprestaciones, que iban desde la posibilidad de nuevos negocios hasta la implicación de sus actividades mercantiles en la actividad hacendística (p.ej., produciendo aquel producto cuyo impuesto recaudaban):

el arrendamiento de rentas constituía un procedimiento de subasta por la que un agente particular -normalmente un mercader- accedía al cobro de dicha una o varias rentas a cambio de un precio determinado durante un período definido en los documentos que regían la contratación. Este hecho, sin embargo, encubría una realidad más amplia y compleja ya que el arrendamiento también se caracterizaba por ser una operación financiera y/o mercantil ligada al crédito y un movimiento de búsqueda de posiciones ventajosas en la producción y tráfico de determinados productos; asimismo, y en tercer lugar, el arrendamiento de rentas formaba parte de un determinado sistema de poder, tanto a nivel regional como en relación a la administración del rey ${ }^{24}$.

Los arrendadores se organizaban en compañías formadas por familiares, socios, fiadores, factores, etc. Su acción alcanzaba un radio sumamente amplio, pues financieros de una ciudad no tenían problemas para entrar en rentas de territorios muy apartados, y también hubo casos de asociación de arrendadores procedentes de ciudades muy alejadas entre $s^{25}$. Algunos fiadores incluso pertenecían a oligarquías urbanas directamente ligadas a los poderosos, como por ejemplo Diego Hurtado de Mendoza, marqués de Cañete, o los Molina, familiares del propio Francisco de los Cobos; y es que en torno a la fiscalidad crecía «un auténtico negocio económico, y por extensión político» ${ }^{26}$. El análisis de este potente negocio fiscal, que generaba

23. María del Pilar Esteves Santamaría, «Toledo en las Cortes de Carlos I: cuestiones de interés general para el reino», en Cuadernos de Historia del Derecho, n 12, 2005, p. 234.

24. David Alonso García, «Poder financiero y arrendadores de rentas reales en Castilla a principios de la Edad Moderna», en Cuadernos de Historia moderna, n³1, 2006, p. 119.

25. Ibídem, p. 126. Véase también María Teresa López Beltrán, «Redes familiares y movilidad social en el negocio de la renta: el tándem Fernando de Córdoba-Rodrigo Álvarez de Madrid y los judeoconversos de Málaga», en Congreso Fiscalidad y sociedad en el Mediterráneo bajomedieval (Málaga, 17-20 de mayo de 2006). [En línea:] http://ssouviron. googlepages.com/ResMaite.htm (Consulta: noviembre de 2008).

26. David Alonso García, «El sistema fiscal castellano (1503-1536)», en Tiempos Modernos: Revista Electrónica de Historia Moderna, n 7, 2002-2003. [En línea:] http://www. tiemposmodernos.org/floridablanca/textoalonso.htm (Consulta: noviembre de 2008). 
redes clientelares y favorecía el intercambio de intereses entre la oligarquía urbana y la monarquía, está permitiendo desvelar algunas cuestiones sobre el equilibrio de poderes en la Edad Moderna. Lo que nos interesa aquí es que la excesiva presión recaudatoria generó una comprensible avidez por hallar modos más o menos lícitos de eludir tal sobrecarga.

Documentalistas e historiadores describen el ansia de los menos pobres por hacerse con algunas tierras y propiedades, acumular todos los requisitos necesarios y ser declarados "hijos de algo». Serlo les permitía alcanzar la exención de tributar y, aliviado el peso, estar más cerca de la prosperidad. Ramón Carande observa cómo «Los comerciantes, no siendo hidalgos de cuna, se desvivían por comprar hidalguías cuando, gracias a sus tratos, su posición medraba ${ }^{27}$, y Manuel Colmeiro, que «Muchos labradores pecheros ganaban cartas de hidalguía por gozar del privilegio de no pechar, y eran los más ricos de la comarca, con lo cual todo el peso de los tributos cargaba sobre los pobres» ${ }^{28}$. Carretero Zamora define este fenómeno como crónico y apunta un hecho sorprendente: en las averiguaciones de la Real Hacienda iniciadas a partir de 1528 los pesquisidores informaron de la connivencia de los concejos y de los falsos hijosdalgos ${ }^{29}$. Efectivamente, las oligarquías urbanas y la nobleza fomentaron la exención solicitándola para criados, labradores, etc., mediante los más variados mecanismos (con el fin de fomentar su dependencia). También parece probado que la permisividad que permitió que amplios sectores sociales eludieran el pago de impuestos se debió a un pacto entre monarquía y oligarquías locales ${ }^{30}$. Por tanto, se trata de un fenómeno de retroalimentación complejo y sofisticado, que a menudo burlaba la ley.

Fundamentalmente era pechero el pueblo llano (artesanos, comerciantes, pescadores, agricultores, etc.), mientras que los hidalgos, nobles y todos los miembros del clero estaban exentos de impuestos. Este privilegio común era poco cuestionado porque las "honras, franquezas, libertades y exenciones" de la nobleza de sangre habían sido otorgadas por ley o consolidadas por la costumbre; sin embargo, las oligarquías estaban obteniendo o comprando los privilegios, una acción que sí se ponía en tela de juicio.

27. Ramón Carande, op. cit., p. 100.

28. Cortes de los antiguos Reinos de León y de Castilla. Cap. XXIV, "Reinado de Don Carlos I y Dońa Juana». [En línea:] http://www.cervantesvirtual.com/servlet/SirveObr as/95791734217821695203346/p0000018.htm (Consulta: junio de 2008)

29. Juan Manuel Carretero Zamora, «Las oligarquías locales y los mecanismos de exención del servicio de Cortes en la época de Carlos V», en Espacio, Tiempo y Forma, Serie IV, Historia Moderna, n 11, 1998, nota 41, p. 23.

30. Ibidem, p. 11-37. 
La razón última por la que la oligarquía no pagaba los impuestos obedeció a un fenómeno simple, ilegal, aunque definitivo y eficaz: eran regidores $\mathrm{u}$ oficiales del concejo. A falta de cualquier otro fundamento jurídico, se diseñó una norma que debía arrastrarse desde tiempo atrás: toda persona con oficio de gobierno era por naturaleza exenta por el mero hecho de ejercerlo. [...] Aunque las protestas de estos abusos eran crónicas desde la época de los Reyes Católicos, el panorama resultó ser aún más preocupante cuando empezaron a recibirse en la Contaduría Mayor los informes de los pesquisidores enviados a realizar las averiguaciones para el reparto del servicio entre los años 1528 y 1532. La primera conclusión a la que llegamos es que la exención por oficio de gobierno era prácticamente general en todo el reino, especialmente en los grandes núcleos de población $^{31}$.

La situación se prolongaría durante mucho tiempo:

En 1566, con motivo de haberse autodeclarado exentos los escribanos de Arévalo y de otros pueblos con sus hijos y descendientes, Felipe II tuvo que ordenar que «de aquí adelante todos y cualesquier Escribanos del Número o del Concejo, así de la dicha villa de Arévalo como de todas las otras ciudades, villas y lugares de estos Reinos y Señoríos, por razón de los dichos no puedan gozar ni gocen de cualquier exención de pechos ellos ni sus hijos ni descendientes [...] y lo mismo mandamos que se cumpla y guarde en cuanto a los Regidores y Jurados y otros oficiales del Concejo de estos Reinos, los cuales por razón de sus oficios no se puedan excusar ni excusen de pechar...».

Tal Orden no debió ser demasiado atendida puesto que, como otras, fue recogida más tarde por la Novísima Recopilación. La razón de «trabajar para la Ciudad» fue excusa muy habitual para que determinados grupos de población fueran declarados exentos por lo Concejos. En determinadas poblaciones llegaron a serlo los boticarios, los hospitaleros, los barberos o los pregoneros $^{32}$.

31. Juan Manuel Carretero Zamora, op. cit., p. 13.

32. Javier María Donézar Díez de Ulzurrun, «Los decretos de la Real Hacienda de 1749, los poderes locales y la representación del reino", Espacio, Tiempo y Forma IV, Historia Moderna, t. 12, 1999, p. 297-320. 


\section{EL CONTEXTO FISCAL APLICADO AL LAZARILLO DE TORMES}

A la luz de esta realidad resulta más fácil hallar un rasgo común a todos los personajes del Lazarillo. Por ser miembros del clero, de la hidalguía o por desempeñar oficios municipales, ninguno de los amos de Lázaro es pechero, sino exento. Incluso el fugaz pintor de panderos, si nos atenemos a una interpretación propuesta por Blecua ${ }^{33}$, es un alcahuete que vive de sus tratos irregulares, en cierto modo como el ciego (que por serlo, y a diferencia de otros pobres, obtiene beneficios legales como mendigar sin licencia, aunque a cambio de obligaciones morales como comulgar ${ }^{34}$; el alguacil, que disfruta de oficio real, también está exento. Por su cuna o por carecer de propiedades, ninguno de ellos paga impuestos. Ni siquiera el clérigo por su sospechosa hacienda de bodigos: el pan cocido estaba exento de alcabala ${ }^{35}$.

Los personajes del Lazarillo forman parte de una sociedad que los especialistas actuales ya no dividen en tres brazos diferenciados (nobleza, clero y estado llano) sino en pueblo común por un lado y, por otro, una «clase social» dirigente formada por nobles, obispos, altos cargos de la administración y «burgueses» sin privilegio jurídico, representantes municipales que coincidían en intereses políticos, sociales y económicos, aunque no llegaran a formar parte de una sola identidad ni de un solo comportamiento político ${ }^{36}$. Esta sociedad existía desde el principio de la Edad Moderna y se prolongó hasta Fernando VI porque favorecía el poder y el control vecinal de las oligarquías urbanas, que además gestionaban la recaudación de impuestos ${ }^{37}$. El énfasis que ponen los estudios fiscales contemporáneos en este nuevo punto de vista dual, que separa al pueblo del poder y el privilegio, permite interpretar ciertos aspectos de la obra.

33. Alberto Blecua, La vida de Lazarillo de Tormes, Madrid, Castalia, 1974, «Introducción» y p. 171. Una alusión figurada que, por cierto, está en consonancia con la forma de describir las costumbres del fraile de la Merced, y que evidencia los tabúes del autor o de la literatura de la época. Lo destacan también Víctor García de la Concha, Nueva lectura del Lazarillo, Madrid, Castalia, 1981, p. 101-104 y Rosa Navarro Durán, Alfonso de Valdés..., op. cit., p. 136.

34. Novísima Recopilación, Tomo III, título XXXIX, ley VIII, año 1523.

35. Ramón Carande, Carlos V y sus banqueros, Madrid, Revista de Occidente, 1949, p. 224.

36. Juan Manuel Carretero Zamora, Cortes, Monarquía, Ciudades. Las Cortes de Castilla a comienzos de la época moderna (1476-1515), Madrid, Siglo XXI, 1999, p. 419-421.

37. Javier María Donézar Díez de Ulzurrun, «Los decretos de la Real Hacienda de 1749, los poderes locales y la representación del reino", Espacio, Tiempo y Forma IV, Historia Moderna, t. 12, 1999, p. 297-320. 
De nuevo es Carretero Zamora quien, al hilo de la Averiguación fiscal ordenada por Carlos V en 1528, aporta información sobre los cargos exentos, especialmente en los grandes núcleos castellanos y andaluces, y cita el siguiente párrafo de una pesquisa: «en la provincia de Segovia hay otros muchos exentos, así como boticarios, barberos, herreros, mesegueros, hospitaleros y pregoneros, que en muchas partes los exentan los concejos porque sirvan los dichos oficios» ${ }^{38}$.

Otro ejemplo aparece en Cuéllar, donde «se evaluaron en 4 el número de pregoneros exentados por el concejo, aunque la exención sólo estaba vigente en tanto sirvieran el oficio» ${ }^{39}$. El de pregonero era un "cargo de funcionario público de Toledo en el que concurren al propio tiempo y en forma contrapuesta el respeto y la autoridad que supuestamente le corresponden a un oficial de la justicia, aunque sea de ínfimo rango, y la baja estimación social» ${ }^{40}$ por su interrelación con el oficio de verdugo.

Por tanto, que Lázaro desea fundirse con la «clase social» privilegiada y exenta es algo manifiesto. Explica su satisfacción por haber obtenido el oficio de pregonero, que aun sin ser oficio de gobierno, gozaba de exención en muchas ciudades y era lo más cerca que podía estar de «los buenos» alguien como él. Por otro lado, el traspaso de oficio público no implicaba gravamen alguno. Y por si quedaran dudas, indica cómo el arcipreste le había mandado alquilar la casa, detalle innecesario y superficial si no se tiene en cuenta que el alquiler no estaba gravado, pero la propiedad sí. Una operación redonda.

Las fugaces alusiones económicas del Lazarillo estarían apuntando certeramente hacia una situación fiscal y política característica del imperio, tan presente en la sociedad que el lector de la época no podría dejar de advertir su parodia. Pero no sólo los personajes parodian una realidad fiscal. Existen otras coincidencias en el mismo sentido.

\section{LOS «PARAÍSOS FISCALES» CASTELLANOS}

Lo que proponían los procuradores poco antes de que estallara la guerra de las Comunidades no era un igualitarismo descabellado, como indicaba Guevara, sino un acto de justicia que acabase con desigualdades flagrantes:

38. Archivo General de Simancas, Contadurías Generales, legajo 768 (Averiguación). Parece adecuado apuntar ahora que, aunque mucho más tarde, el padre del Buscón de Quevedo es barbero en Segovia.

39. Juan Manuel Carretero Zamora, «Las oligarquías locales y los mecanismos de exención del servicio de Cortes en la época de Carlos V», en Espacio, Tiempo y Forma, Serie IV, Historia Moderna, n 11, 1998, p. 23, nota 40.

40. Antonio Vilanova, Barcelona, Lumen, 1989, p. 282. 
que por cuanto está dispuesto por las leyes destos reinos, que las villas e lugares que agora tienen e poseen algunos señores, que son de ellos sacadas algunas ciudades e villas que gozan de sus términos, pazcan e corten como los otros vecinos de las tales ciudades e villas. Que pechen e contribuyan en los repartimientos, e pechos de cercas, e puentes e fuentes, e guardas e pleitos, e defensa e ensanchamientos de términos, e por favor de algunos grandes caballeros cuyos son, no se guarde ni cumple lo que Sus Majestades mandan. Que agora, e de aquí adelante, la hagan guardar e cumplir. E si en ello fueren negligentes, pierdan los oficios e todo el salario de ellos. E los señores de los tales lugares no lo impidan, so pena de perder el señorío e propriedad de los tales lugares, e que sean de la corona real, debajo de la jurisdición de la tal ciudad, villa o lugar de cuya saca son. E que no se pueda más hacer merced de ello, ni enajenarse como de bienes del patrimonio e corona real ${ }^{41}$.

Importa ahora recordar la diferencia entre lugares de realengo y lugares de señorio, imperante en el s. XVI, pues lo que los procuradores reclamaban era igualdad de trato entre ambos tipos de término. Principalmente, los realengos se hallaban bajo la jurisdicción real, y los lugares de señorío secular (o eclesiástico: abadengo) dependían de un señor o de las órdenes eclesiásticas. Los procuradores denunciaban que la autonomía jurídica de los señoríos fomentaba desigualdades porque los señores podían amparar a los habitantes de su señorío en materia fiscal, fomentando así el fraude.

Hay muchos vecinos pecheros en los lugares de la provincia de Madrid que se llaman exentos: unos por paniaguados de señores y personas favorecidas, y algunos por paniaguados en la villa de Madrid y su tierra... y otros muchos particulares que son exentos por posesión que tienen de no pechar, y otros por oficios nobles que tienen, así como letrados y escribanos... generalmente los dichos exentos son los más ricos y mejor librados del pueblo ${ }^{42}$.

Esta situación local era común en los señoríos: el amparo pseudolegal de los señores hacía que

41. Prudencio de Sandoval, Historia de la vida y hechos del Emperador Carlos V, Libro VII, año 1520, cap. I «La comunidad escribe al rey». [En línea:] <http://www.cervantesvirtual. com/servlet/SirveObras/90904584878552620270479/index.htm> (Consulta: mayo de 2008)

42. Ibidem, p. 18, cita de la Averiguación de 1528 en provincia de Madrid (adiciones) conservada en el Archivo General de Simancas, Contadurías Generales, leg. 768. 
las desigualdades que se producían en el interior de cada provincia eran enormes $y$, en ocasiones, absolutamente absurdas, sólo comprensibles por la existencia de sistemas de pago alternativos a la capitación [creados por la oligarquía] [...] El propio Carlos V tuvo que reconocer esta realidad, y en 1525 se dirigió a las ciudades castellanas prometiendo criterios más racionales de reparto y, sobre todo, que aligeraría la carga soportada por los realengos, ya que era evidente que el sistema de reparto vigente favorecía a las jurisdicciones de señorío ${ }^{43}$.

Esta situación podría estar manifestándose en el Lazarillo de Tormes, puesto que el itinerario geográfico del mozo pasa exclusivamente por una selección de señoríos.

Los señoríos del Lazarillo, por otra parte, revelan algunos puntos en común:

Tejares, aldea de Salamanca donde nace Lázaro, formaba parte de la villa de Alba y por tanto estuvo bajo la jurisdicción del II duque de Alba, Fadrique Álvarez de Toledo, hasta 1531; le sucedió su nieto, el Gran Duque o III duque de Alba, Fernando Álvarez de Toledo, nacido en 1507 y muerto en 1582. Como vecindad de Alba se hallaba anexionada a la iglesia y colación de Santo Domingo. Se conservan diversos documentos que atestiguan la existencia de aceñas en Tejares ${ }^{44}$. Por sus grandes favores a la monarquía, la casa de Alba obtuvo desde 1460 el privilegio de recaudar para sí la alcabala, aunque fuera un impuesto regio, en todos los lugares de su jurisdicción.

Salamanca ciudad, donde Lázaro vive con su madre viuda, el negro Zaide y su hermanastro, gozaba de amplias exenciones desde los tiempos de Enrique $\mathrm{IV}^{45}$. En la obra se hace mención del mayordomo de La Magdalena,

43. Juan Manuel Carretero Zamora, «Los servicios de las Cortes de Castilla en el siglo XVI», en Cuadernos de Historia Moderna, n² 21, 1998, p. 22.

44. Archivo de la Real Chancilleria de Valladolid, Real Audiencia y Chancilleria de Valladolid, Registro de Ejecutorias (28-9-1502).

45. Un «Privilegio de varias exenciones y franquezas á los vecinos y moradores de la ciudad de Salamanca del muro adentro", otorgado por Enrique IV el 28 de junio de 1465 (y que comprometía a sus descendientes), proveía que «todos los vecinos é moradores que moraren en la dicha ciudad de Salamanca de los muros adentro, legos é clérigos, fuesen quitos, é escusados de todo pecho, é de todo pedido, é de todo tributo que haya nombre de pecho [...] e por los faser más bien é merced, que los vecinos é moradores de la dicha ciudad andoviesen salvos é seguros por todas las partes de estos dichos Reinos e que non pagasen portazgo, nin montazgo, nin pasage nin peage, nin asadura, nin barcage, nin roda, nin castillería, nin otro servicio alguno, nin derecho nin tributo alguno [...] de aquí adelante para siempre jamás». Véase: Tomás González, Colección de cédulas, cartas-patentes, provisiones, reales órdenes y otros documentos concernientes a las provincias Vascongadas: Copiados de orden de 
administrador y jefe principal del servicio, que es quien manda hacer una pesquisa para comprobar que Zaide roba en las caballerizas; cuando Lázaro alude de nuevo a él como «dicho comendador», se refiere a su pertenencia a la orden de Alcántara (la iglesia de La Magdalena había sido fundada a finales del s. XII por don Esteban, arcipreste de Alba, en su propia casa y cedida por el cabildo en 1205 a la orden de Alcántara). Al dominio de la orden de Alcántara pertenecían también Alba de Tormes y Salamanca; el último maestre de la orden fue Alonso de Monroy (muerto en 1511), de la familia de María de Monroy o María la Brava, lo que establece la posibilidad de que la mención de La Magdalena estuviese centrando la atención sobre una parte de la ciudad que formaba parte del célebre bando de Santo Tomé, enfrentado desde el siglo XV con el bando de San Benito, y en consecuencia, sobre sus integrantes ${ }^{46}$. Se requeriría un estudio más complejo para determinar las líneas ideológicas que pueden estar señalándose aquí, pero en cualquier caso se perciben coincidencias de estos clanes con los bandos que apoyaron a Enrique IV y a la Bertraneja.

Sólo podemos apuntar ahora, siguiendo el signo marcado por las alusiones familiares, que al entorno familiar de los Álvarez de Toledo y de los Zúñiga, familias de la casa de Alba principales en Salamanca y Toledo, pertenecía Fernando Álvarez Ponce de León, aspirante al condado de Arcos que, a partir de 1523, inició un pleito con el legítimo duque de Arcos; por tanto parece coherente que Lázaro se refiera a él también en el Tratado Tercero y cierre así un círculo de alusiones ${ }^{47}$. El señorío de Arcos había obtenido exención de impuestos a perpetuidad.

Es significativo que las correcciones que efectuó la Contaduría Mayor para compensar las desigualdades a partir del servicio de 1535 afectaran muy especialmente a dos de las ciudades del Lazarillo: Salamanca (con un incremento del 4,85\% al 6,65) y la Mesa Arzobispal de Toledo, que junto con la ciudad de Toledo había gozado de amplias exenciones hasta entonces

S.M. De los registros, minutas y escrituras existentes en el Real Archivo de Simancas. Libros de Privilegios y Confirmaciones en el Real Archivo de Simancas: libro no 4 de los Privilegios del Rey Don Enrique cuarto, art. Salamanca, Madrid, Imprenta Real, 1830. [En línea:] http://books.google.es/books?id=ouULAAAAYAAJ (Consulta: noviembre 2008).

46. José María Quadrado, España: sus monumentos y artes, su naturaleza y su historia, Tomo III, Cap. I: «Memorias de Salamanca». [En línea:] http://www.biblioteca.org.ar/libros/70836.pdf (consulta: enero de 2009)

47. María del Carmen Vaquero Serrano, «El Conde de Arcos: ¿̨un rasgo más de la tolenidad del Lazrillo de Tormes? ¿Otra ironía», en Lemir, n 12, 2008, p. 49-92. 
y cuya media tributaria aparece siempre entre las más bajas del reino ${ }^{48}$. «Los pecheros de las localidades más próximas a Toledo (Argés, Cobisa, Nambroca y Burguillos) no pagaban servicio porque toda la propiedad estaba en manos de familias (con oficio de regiduría o juradería) toledanas ${ }^{49}$.»

Almorox, villa toledana que el muchacho atraviesa con el ciego, había sido otorgada a Juan Pacheco, I marqués de Villena, mediante privilegio de Enrique IV el 25 de mayo de $1470^{50}$. Le sucedió su hijo Diego López Pacheco, II marqués de Villena y II duque de Escalona, y a éste su hijo del mismo nombre. Uno de los dos últimos debía encabezar el señorío en el momento en que se escribió la obra.

Escalona, como Lázaro se ocupa curiosamente de resaltar, es la «villa del duque de ella»: efectivamente, era un señorío. Fue donada en 1472 por Enrique IV a Juan Pacheco, que se casó contra su voluntad con Juana de Luna (hermana de don Álvaro de Luna, condestable de Castilla) ${ }^{51}$; cuando consiguió anular este matrimonio se casó con María Portocarrero, de quien nacieron catorce hijos y tres linajes: Pacheco, Portocarrero y Téllez Girón.

El primogénito Diego López Pacheco, II duque de Escalona, se casó con María de Luna, con quien no tuvo sucesión; de su segundo matrimonio con Juana Enríquez nació Diego López Pacheco, III duque de Escalona. El autor del Lazarillo podría estar refiriéndose al II duque de Escalona, muerto el 6 de noviembre de 1529, o al III duque, también Diego López Pacheco de nombre, que murió en 1556.

Adviértase que los Pacheco estaban emparentados con los Álvarez de Toledo desde que el 4 de agosto de 1493 firmaran capitulaciones matrimoniales Beatriz Pacheco y Fernando Álvarez de Toledo, secretario del Consejo Real, con motivo del desposorio de María Ponce de León, hija de Luis Ponce de León, IV conde de Arcos, con Antonio Álvarez Zapata ${ }^{52}$. Del 12 de mayo de

48. José Manuel Carretero Zamora, «Los servicios...», p. 24.

49. Ibídem, p. 27.

50. Se conserva más información en Archivo Histórico Nacional, Sección Nobleza, Archivo de los Duques de Frías.

51. Aportamos esta información por si pudiera ser significativa para el estudio de la procedencia genealógica de Juan de Luna, continuador del Lazarillo, aunque ya ha sido minuciosamente analizada por María del Carmen Vaquero Serrano, "Juan de Luna, continuador del Lazarillo: ¿¿Miembro de la toledana familia Álvarez Zapata?», en Lemir, n 8, 2004, p. 1-18. Ha demostrado significativas concordancias entre algunas obras picarescas y la Crónica de don Álvaro de Luna Rosa Navarro Durán, Novela Picaresca I, Madrid, Biblioteca Castro, 2004, Prólogo, p. XLIV.

52. La documentación se conserva en el Archivo Histórico Nacional, Sección Nobleza, Archivo de los Duques de Osuna; véase también María del Carmen Vaquero Serrano, art. cit., en Lemir, n' ${ }^{\circ}$, 2004, p. 1-18. 
1495 es la carta de dote y arras otorgada por Fernando Álvarez de Toledo y su esposa a favor de su nuera María Ponce de León.

La oligarquía de Escalona inició un pleito en 1536 para conseguir la exención del servicio de su población de muros adentro ${ }^{53}$. Entablar pleitos interminables con la Real Hacienda fue una estratagema habitual: dada la inoperancia judicial de los tribunales de hacienda, podía lograrse una «exención» temporal que durase décadas, pues se suspendía el cobro del servicio en tanto el pleito "estaba vivo».

Torrijos fue vendida el 11 de enero de 1482 por el arzobispo Alonso Carrillo de Toledo a Gutierre de Cárdenas, comendador mayor de León, contador mayor de los Reyes Católicos y alcalde mayor de Toledo, señor de Elche, Crevillente, Aspe y Torrijos, fundador del mayorazgo de Maqueda y de Baena (que se convertiría en marquesado en 1497). Fue declarada villa ese mismo año. Cárdenas reconstruyó la muralla de la villa y transformó en convento el magnífico palacio que Pedro I de Castilla había erigido en ella ${ }^{54}$

Maqueda formaba igualmente parte del señorío de la familia Cárdenas. La escritura en que procuradores, alguaciles y regidores del concejo de Maqueda reconocen a Gutierre de Cárdenas y a su esposa como señores de la villa es del 26 de febrero de 1483. La fundación del mayorazgo de Maqueda por parte de Gutierre de Cárdenas tuvo lugar el 28 de enero de $1503^{55}$. El hijo de Gutierre de Cárdenas, Diego de Cárdenas y Enríquez, recibió de Carlos V el título de I duque de Maqueda en 1529. Los duques de Maqueda tenían palacio en Torrijos.

Cabe destacar que la tercera hija de Gutierre de Cárdenas, María de Cárdenas Chacón y Enríquez, se casó con Francisco de Zúńiga y Avellaneda (que murió en 1536), descendiente de los Álvarez de Toledo ${ }^{56}$. En 1521

53. Juan Manuel Carretero Zamora, «Las oligarquías locales...», p. 30-31.

54. Se conserva documentación sobre el señorío de Cárdenas en el Archivo Histórico Nacional, Sección Nobleza, Archivos de los Duques de Frías y los Duques de Osuna.

55. La documentación se conserva en el Archivo Histórico Nacional, Sección Nobleza, Archivo de los Duques de Baena.

56. Fadrique Álvarez de Toledo, II duque de Alba, se casó con Isabel de Zúñiga, condesa de Sevilla, y tuvieron a: 1. Leonor Álvarez de Toledo; 2. García Álvarez de Toledo (que no pudo heredar el ducado por morir antes de 1512; sus hijos fueron Catalina, María y Fernando Álvarez de Toledo y Pimentel, siendo este último el III duque de Alba o Gran Duque entre 1531 y 1582); 3. Pedro Álvarez de Toledo y Zúńiga, virrey de Nápoles; 4. Aldonza Leonor Álvarez de Toledo y Zúńiga. Los Zúńiga, en 1454, contaban con rentas superiores a los cuatro millones de maravedís (unos 27.000 ducados de aquel momento) y a 15 a comienzos del siglo XVI (40.000 ducados), según consta en Los Trastamara y la unidad española: 1369-1517. Madrid, Ediciones Rialp, 1981, p. 61. 
este Francisco Zúniga y Avellaneda, conde de Miranda, había fundado mayorazgo a favor de su segundo hijo, Gutierre de Cárdenas; el mayorazgo fue confirmado por Carlos V el 30 de mayo de $1535^{57}$. La consolidación de esta urdimbre familiar queda plasmada en el documento titulado «Árbol del mayorazgo de Maqueda, su apellido Cárdenas. Desde Gutierre de Cárdenas, comendador Mayor de León, con Teresa Enríquez, hasta Antonio de Cárdenas Manrique de Lara, Duque de Nájera, Fernando de Zúñiga Conde de Miranda y Diego de Zúñiga y Cárdenas» ${ }^{58}$.

La actuación más relevante de los Cárdenas es la que revela nada menos que Gonzalo Fernández de Oviedo en sus Batallas y quinquagenas:

Avés de saber que ví yo en la corte de los Reyes Católicos, don Fernando e dońa Isabel, de gloriosa memoria (siendo yo paje muchacho), que don Gutierre de Cárdenas, comendador mayor de León, e don Juan Chacón, adelantado de Murcia, y Rodrigo de Ulloa, contadores mayores de Castilla, por causas de sus grandes ofiçios trayan toda la masa de la Hacienda Real entre manos, [e] eran segundos seńores de Castilla e de León e sus anexos. E lebantóse un ombrecillo de buen ingenio, llamado Diego de la Muela, que yo le ví e conocí, persona de quien nenguna quenta se hacía, pero de buen natural, e dio tal aviso al rey e reyna en sus rentas e hacienda Real, que les mostró palpable cómo los contadores mayores eran señores de la Hacienda Real e eran muy servidos e aprovechados, e que demás e allende desto, gozaban e llevaban oficiales recaudadores otra suma incontable de dinero, e lo qual todo era a costa de los vasallos e pueblos Reales e en gran perjuicio del patrimonio e hazienda Real. Para evitar todo esto e que aquellas ilícitas ganancias e robos se escusasen, que los súbditos naturales que los pagaban no fuesen por indirectas vías molestados, e que la hacienda Real no se menoscabase, ofrecióse a dar tal medio e orden con que Dios fuese muy servido e la renta Real asegurada, e que los robos e coechos cesaran, e aquellas demasías se quedasen con sus dueños. E fue oydo e acogido el parecer de Diego de la Muela de aquellos buenos príncipes, e dio orden en los encabezamientos, e los mismos pueblos e ciudades e villas tomaron sobre sí las rentas Reales, e ahorraron todo lo que los arrendadores e recaudadores e otros oficiales llevaban; e aseguróse la renta al rey. Pero

57. La documentación se conserva en el Archivo Histórico Nacional, Sección Nobleza, Archivo de los Duques de Frías.

58. Archivo Histórico Nacional, Sección Nobleza, Archivo de los Duques de Baena. 
dio con la magestad e fausto e potencia de los contadores mayores en tierra; e aunque no del todo, anichilóse mucho el ynterés e grandeza de sus oficios ${ }^{59}$.

Toledo, como es bien sabido, era señorío eclesiástico y gozaba de importantes privilegios por ello,

lo cual no implica que los señores (sobre todo los eclesiásticos) no fueran beligerantes a la hora de lograr beneficios fiscales en sus jurisdicciones a través de obtener un coeficiente maravedí/pechero más bajo que en los realengos, o bien obtener simplemente la exención completa de los vecinos asentados en sus jurisdicciones. $\mathrm{Y}$, sobre todo, apoyaron a las oligarquías locales en los numerosos pleitos que ante la real hacienda se interpusieron con la finalidad de lograr la ansiada exención tributaria ${ }^{60}$.

Ya en 1523 la ciudad de Toledo había pedido al rey que se le concediese

un nuevo encabezamiento por 15 o 20 ańos, que les hiciese alguna merced a la baja y que la renta no se ejecutase sobre los bienes propios de la ciudad ni sobre las personas y bienes de los regidores, jurados $\mathrm{u}$ otros oficiales, "pues ellos no entienden en ello por fin ni ynteresse particular suyo sino por el bien publico de la çibdad» ${ }^{61}$.

Cremades Griñán puntualiza que el estado eclesiástico estaba exento del pago de la alcabala en lo que se refiere a la compra, aunque no en las que hicieren por mercadería, trato, granjería o negociación ${ }^{62}$. El arzobispado estuvo en manos de Alonso Fonseca entre 1523 y 1534, y le sucedieron Juan Pardo Tavera (1534-1545) y Juan Martínez Silíceo (1545-1557). Entre la nobleza, los Álvarez de Toledo eran señores principales de la ciudad, como atestigua el importante volumen de documentación acumulada en el Archivo Condal de Cedillo referente a esta familia y sus diversas ramas.

Los dos pleitos más célebres y relevantes de Toledo durante la primera mitad del siglo XVI son de orden fiscal, y atañen de nuevo a las familias que hemos destacado arriba. Uno es el sostenido conflicto de poderes entre el

59. Gonzalo Fernández de Oviedo, Batallas y quinquagenas, Madrid, Real Academia de la Historia, 1983. Tomo II, Batalla I, Quinquagena II, Diálogo XVIII, p. 53-54.

60. Juan Manuel Carretero Zamora, «Las oligarquías...», p. 26.

61. María del Pilar Esteves Santamaría, «Toledo en las Cortes de Carlos I: cuestiones de interés general para el reino", Cuadernos de Historia del Derecho, $\mathrm{n}^{\circ}$ 12, 2005, p. 237.

62. Carmen María Cremades Griñán, «Notas al sistema de encabezamiento de alcabalas (1536-1556)», en Homenaje..., p. 321. 
prior de San Juan, fray Álvaro de Zúñiga, que interfería en la jurisdicción de Fonseca al mandar visitas canónicas a las iglesias sanjuanistas en territorio toledano para la percepción de los diezmos, lo que motivó una provisión del emperador en 1526 para que el gran prior no molestase al arzobispo en el ejercicio de su jurisdicción ordinaria; orden que no fue obedecida ${ }^{63}$. Por otro lado, las órdenes de Santiago y San Juan siempre se mostraron activas en materia fiscal, y apoyaron a sus pecheros con el argumento que la exención de servicio estaba contemplada en los privilegios concedidos antiguamente por la monarquía a la orden ${ }^{64}$.

El otro pleito al que nos referimos es el que sostuvo durante más de ochenta años la rama toledana de la familia Zúñiga, que reclamaba el condado de Belalcázar aduciendo que le pertenecía legítimamente por concesión real, contra la ciudad de Toledo. El litigio, iniciado en 1462, tenía una gran relevancia política porque podía afectar a la relación de la monarquía con los Zúñiga y otras familias nobiliarias y también a su relación con la ciudad de Toledo. En las Cortes de Toledo de 1525, las de Madrid de 1528, las de Segovia en 1532 y de nuevo en Madrid en las de 1534, en Valladolid en 1537 y en Valladolid en 1542 los procuradores toledanos reclamaron al monarca una solución definitiva por los altos costes de tan largo proceso. El "pleito era muy importante al servicio del rey porque las alcabalas de estos lugares a él le pertenecían» ${ }^{65}$.

En suma: Lázaro se mueve por las tierras de los duques de Alba (familia Álvarez de Toledo, emparentada con los Ponce de León señores de Arcos), de los duques de Escalona y Villena (familia Pacheco, emparentada con los Álvarez de Toledo), del duque de Maqueda (familia Cárdenas, emparentada con los Zúñiga que entroncaban con los Álvarez de Toledo desde el matrimonio del II duque, Fadrique Álvarez de Toledo, con Isabel de Zúñiga, hija del I duque de Béjar, Salamanca) y del arzobispado de Toledo (donde los Álvarez de Toledo y los Zúñiga eran principales) ${ }^{66}$.

63. Ventura Leblic, "Cronología del pleito sostenido por los arzobispos de Toledo y los priores de San Juan en Castilla (s. XIV-XVIII) sobre percepción de diezmos», en Actas del Primer Simposio Histórico de la Orden de San Juan en España, Toledo, Diputación Provincial de Toledo, 2003, p. 555-558. Los conflictos se iniciaron en el siglo XIV y no concluyeron hasta finales del XVIII.

64. Juan Manuel Carretero Zamora, «Las oligarquías...», p. 26.

65. María del Pilar Esteves Santamaría, «Los cuadernos particulares de Toledo en las Cortes de Carlos I: cuestiones municipales», en Cuadernos de Historia del Derecho, $\mathrm{n}^{\circ} 11$, 2004, p. 211.

66. El Archivo Histórico Nacional conserva abundante documentación sobre procesos de exención de impuestos relacionados con estas familias, pero excede al propósito y los límites de este trabajo tratar de evaluar si estos procesos son más numerosos que los de otras 
Esta rudimentaria relación genealógica permite únicamente señalar la intencionalidad del autor del Lazarillo en la selección del itinerario geográfico del mozo; confirmar alusiones biográficas debería ser materia para un estudio más profundo. En cualquier caso el itinerario, por sí solo, parece apoyar la denuncia que subyace en la obra mediante la elección de señoríos con amplias exenciones, que son además territorios donde determinadas familias nobiliarias destacaron en la búsqueda de desorbitados privilegios fiscales, hasta el punto de emprender litigios largos y célebres.

\section{LAS BOCAS DE LÁZARO: METÁFORAS DE LA SISA}

El Lazarillo es la narración en primera persona de la vida del protagonista, un pregonero que paradójica y esforzadamente asegura, a lo largo de todo el texto, que sabe mantener la boca cerrada y que cuenta sólo lo que conviene y siempre por algún motivo razonable. Lázaro no sólo gestiona la información, sino que presume de saber hacerlo:

Tratado Primero:

- «Huelgo de contar a Vuestra Merced estas niñerías para mostrar cuánta virtud sea saber los hombres subir siendo bajos, y dejarse bajar siendo altos cuánto vicio.»

- «...como adelante Vuestra Merced oirá»

- «le hacía burlas endiabladas, de las cuales contaré algunas, aunque no todas a mi salvo»

Tratado Segundo:

- «no digo más, sino que...»

- «De lo que sucedió en aquellos tres días siguientes ninguna fe daré, porque los tuve en el vientre de la ballena, mas, de cómo esto que he contado oí, después que en mí torné, decir a mi amo, el cual a cuantos allí venían lo contaba por extenso"

Tratado Tercero:

casas nobiliarias, o si estos contienen alguna característica jurídica en común. Sí se pone de manifiesto la existencia de un factor de identificación en la adscripción histórica de estas familias nobiliarias al lado de Enrique IV en la guerra por la sucesión: en 1455 Enrique IV había llegado a Sevilla con su valido Juan Pacheco y su aliado el conde de Arcos (Ponce), que en 1471 y 1474 apoyaron a Juana la Beltraneja contra el bando del duque de Medina Sidonia, que defendía a Isabel la Católica. Esta filiación ideológica seguía marcando diferencias y bandos en la Castilla de Carlos V. Adviértase también que Quevedo, que consolida con el Buscón diversos rasgos del Lazarillo y fija determinadas características del género de la picaresca, atribuye el nombre de Zúñiga al converso Diego Coronel. 
- «yo le satisfice de mi persona lo mejor que mentir supe, diciendo mis bienes y callando lo demás, porque me parecía no ser para en cámara»

- «Y por evitar prolijidad...»

\section{Tratado Cuarto:}

- «...y por otras cosillas que no digo, salí de él»

Tratado Quinto:

- «Y porque todos los que le veía hacer sería largo de contar, diré uno muy sutil y donoso, con el cual probaré bien su suficiencia»

- «el cual no quiero nombrar por su honra»

- «certifico a Vuestra Merced que...»

- «como tengo dicho a Vuestra Merced»

- "Y así lo hice porque me cumplía, aunque, después que vi el milagro, no cabía en mí por echallo fuera, sino que el temor de mi astuto amo no me lo dejaba comunicar con nadie, ni nunca de mí salió, porque me tomó juramento que no descubriese el milagro y así lo hice hasta agora»

Tratado Sexto:

- «yo subí para venir a alcanzar buena vida, porque mi boca era medida»

\section{Tratado Séptimo:}

- «cargo de pregonar los vinos [...] y declarar a voces sus delitos»

- «malas lenguas, que nunca faltaron ni faltarán, no nos dejan vivir, diciendo...»

la boca»

- «quisiera ser muerto antes que se me hubiera soltado aquella palabra de

- «juré nunca más en mi vida mentalle nada de aquello»

En el primer y último tratado, la boca y el habla de Lázaro cobran primer plano: primero porque proyectan su historia, después porque de ellas depende su estabilidad.

Por otro lado, existen diversas imágenes en que el mozo abre hendiduras semejantes a bocas para sisar; interesante parte de su aprendizaje. Así, las «sangrías mal hechas en los costales de los que allí a moler venían», es decir, rajar los sacos de trigo para sisar su contenido, le cuesta al padre de Lázaro la cárcel. Más adelante Lázaro revive aquel acto delictivo, pues «sangra» el fardel de lienzo donde el ciego guarda el pan y todas las cosas, "que por la boca se cerraba con una argolla de hierro y su candado y llave», y lo descose para extraer comida ( del un lado del fardel descosía y tornaba a coser, sangraba el avariento fardel»).

En la boca guarda las medias blancas que consigue hurtar al ciego, y es de la boca del jarro de donde bebe directamente al principio, con una paja larga de centeno. Más adelante practica de nuevo una hendidura en el contenedor 
del vino, agujereando el jarro y tapando el agujero con una tortilla de cera que se abre y se cierra como una boca.

De nuevo, Lázaro abre una «boca» en el arca del clérigo clavándole un cuchillo hasta que "se me rindió y consintió en su costado", por cuya hendidura puede ejercer de nuevo una sisa consistente en roer y medrar parcialmente los panes. Por fin, el clérigo descubrirá el engaño oculto en su boca, que «desde que viví con el ciego, la tenía tan hecha bolsa que me acaeció tener en ella doce o quince maravedís, todo en medias blancas, sin que me estorbase el comer». La llave oculta en ella silba, y el clérigo descubre el engaño.

Las imágenes relacionadas con la boca son de dos clases: las que se refieren al acto del habla, que Lázaro cree controlar, y las que están relacionadas con el hambre, incontrolable y cuyo único remedio es la sisa; pues en todo momento el mozo se muestra a sí mismo no robando enteramente los comestibles de sus amos, sino menguándolos, reduciéndolos como quien los gravara.

A lo largo de su vida ha aprendido lo caro que cuesta abrir la boca tanto en sentido material como figurado. Aun así lo hace ahora, con incógnitas consecuencias. El motivo para semejante lance debe ser muy bueno.

\section{Hipótesis FINAL: LA PALABRA SERVICIO}

Rosa Navarro observa que el prólogo del Lazarillo no es unitario, sino que se produce un abrupto cambio de persona: primero habla el autor, y luego el protagonista de la obra dirigiéndose a Vuestra Merced. El paso de uno a otro sin solución de continuidad puede ser consecuencia de la manipulación editorial: probablemente una página comprometedora fue arrancada al inicio de la obra, con alguna alusión impublicable ${ }^{67}$.

67. Es la investigación de la profesora Rosa Navarro, que fija la gestación de la obra en la década de 1520 y demuestra la autoría de Alfonso de Valdés, la que nos ha llevado a leer el Lazarillo como el producto de un periodo en que la problemática fiscal fue determinante. Las cuestiones sobre la autoría de la obra quedan fuera del alcance y propósito de este artículo, pero no podemos dejar de señalar una concordancia con el Diálogo de Mercurio y Carón, en cuyo Libro II Alfonso de Valdés pone en boca de un ánima una peculiar consideración sobre la justicia fiscal: "Y acuérdate que no pagan pechos o servicios los ricos, mas los pobres. Inclínate antes a poner sisas o imposiciones sobre la seda que sobre el paño, sobre las viandas preciosas que sobre las comunes, porque aquello compran los ricos y esto otro los pobres", comentario significativo y excepcional en la literatura de la época, como ya señaló Martín de Riquer. Aunque también cabe destacar que la voluntad de denuncia socioeconómica que rastreamos aquí y la ausencia de crítica al sistema concuerda igualmente con Diego Hurtado 
Observamos ahora que es en la primera frase conservada del parlamento del pregonero, inocua pero estrictamente necesaria para la comprensión del texto, donde se halla otra marca económica, fundamental para la lectura, que los editores consideraron que debía prevalecer. Dice Lázaro: «Suplico a Vuestra Merced reciba el pobre servicio de mano de quien lo hiciera más rico si su poder y deseo se conformaran».

Tras el estudio precedente, identificadas otras alusiones fiscales del texto y perfilado el sentido económico de términos hoy más ambiguos, debemos plantearnos una pregunta: ¿qué ocurriría si interpretáramos la palabra «servicio» en su sentido económico, es decir, en su acepción material? Supongamos que al hablar del servicio Lázaro no está hablando de una labor o utilidad, sino del tributo directo que se otorgaba a la corona. El significado de la obra se modifica, y no poco. Obsérvese que califica el servicio de "pobre», es decir escaso, y que redunda en el aspecto material al asegurarle a Vuestra Merced que quien lo entrega «lo hiciera más rico si su poder y su deseo se conformaran", pues desearía entregarle una suma mayor si ello fuera posible (aunque toda la obra es un alegato contra esta posibilidad, por supuesto).

Lázaro se muestra a sí mismo como uno más de cuantos buscan prosperar, medrar y eludir tributos: este ha sido su aprendizaje y es lo que ha visto en su entorno señorial. Se justifica con la ley de la costumbre. Además, aduce que ser pregonero es oficio real, y hasta indica que carece de propiedad, precisamente porque «la propiedad se va a convertir en una de las magnitudes fundamentales para la asignación del servicio y, como veremos más adelante, en una fuente de conflicto y manipulación de la masa tributaria» ${ }^{6}$. El pago de este impuesto se calculaba de modo individual, de acuerdo con la renta y el patrimonio de cada pechero y su lugar de residencia. Por tanto, estaría hablando de un servicio pobre, reducido, que entrega después de aplicarle una de sus habituales «sisas» y sólo porque se lo reclaman.

Lázaro va disfrazándose de hombre de bien («uno de los buenos»: alguien que aspira a un nuevo modelo de honra) con una serie de valores que se corresponden, paródicamente, a los cánones del homines novi, como indicó

de Mendoza, cuya autoría se señaló desde antiguo. En delicada posición tras la guerra de las Comunidades, conocedor de las penurias del pueblo y mediador en múltiples litigios familiares por causas fiscales, tuvo como administrador de su hacienda a Juan López de Velasco, cronista a quien se encargó la censura del Lazarillo y en cuyo inventario de libros aparece la obra. Este imprescindible descubrimiento documental se puede consultar en Mercedes Agulló, A vueltas con el autor del Lazarillo de Tormes, Madrid, Calambur (Biblioteca Literae 21), 2010.

68. Juan Manuel Carretero Zamora, «Los servicios de las Cortes de Castilla en el siglo XVI», en Cuadernos de Historia moderna, n² 21, 1998, monográfico IV, p. 26. 
ya hace mucho Víctor García de la Concha: «Su objetivo es el logro del reconocimiento de nobleza, por lo que la "carrera de vivir" es proyectada como curriculum sobre la pauta de las vías que en la sociedad conducen a los homines novi: la virtud, el valor, la hombría de bien ${ }^{69}$. Añadiríamos ahora que en ese "curriculum» existe un ingrediente importante: la exención tributaria, objetivo oculto pero no menor de la carrera hacia la hidalguía en este periodo de la historia castellana. Nos mantenemos en un primer nivel de lectura, observando únicamente un progreso material que concluye «el mismo año que nuestro victorioso emperador en esta insigne ciudad de Toledo entró", momento en que se cierra el arco profesional que ha recorrido desde la pobreza hasta la estabilidad económica (vinculada a la matrimonial, cuyas dudas zanja la promesa del arcipreste).

Matizaba García de la Concha:

No veo inconveniente en aceptar que Lázaro ha planteado la narración de su vida en conexión con la coyuntura del caso que en el tracto del tratado VII le amenaza de infamia. Pero en modo alguno, como Rico sugiere a contrapunto de su propia lectura del Secretum, como "exculpación frente a la calumnia» y haciendo gravitar todo el relato sobre el dicho caso. Un análisis de detalle nos mostrará, más adelante, cómo el peligro mayor que tal caso encerraba ya ha sido despejado cuando Lázaro escribe, y cómo éste incluye la superación del obstáculo en su nutrido palmarés: un motivo más, y supremo, de ostentación y honra. No. La conexión ha de establecerse, a mi juicio, en esa franja marco de la novela, coherente con su lógica interna ${ }^{70}$.

La narración mantiene un ritmo in crescendo que alcanza su máxima cumbre en «el caso» del amancebamiento; pero recordemos que en la primera frase de la obra el autor anunciaba: «Yo por bien tengo que cosas tan señaladas, y por ventura nunca oídas ni vistas, vengan a noticia de muchos y no se entierren en la sepultura del olvido». El amancebamiento, por sí solo (y aunque se pudiera vislumbrar detrás de sus protagonistas alguna identidad principal), no podía representar un gran escándalo para el lector en un momento en que los hijos naturales de obispos y arzobispos eran aceptados y reconocidos por la monarquía; las leyes lo prohibían reiteradamente y sin eficacia, y la tradición literaria lo recogía y lo denunciaba desde mucho atrás. Es más: volviendo al tiempo interno de la obra, indicaba García de la Concha que el peligro mayor que el amancebamiento encerraba ya había

69. Víctor García de la Concha, Nueva lectura del Lazarillo, Madrid, Castalia, 1981, p. 211.

70. Ibidem, p. 82. 
sido despejado cuando Lázaro empieza a hablar. Entonces ¿cómo podría ser "el caso» una noticia señalada y nunca vista ni oída?

Existe una cuestión abierta que enlaza estrictamente con el presente de la carta. Y es una promesa aún sin cumplir cuando termina el relato. Cuando Lázaro cuenta cómo planteó al arcipreste las habladurías que corrían en torno a su situación, observa: "Porque allende de no ser ella mujer que se pague de estas burlas, mi señor me ha prometido lo que pienso cumplirá». El religioso le asegura: "Ella entra muy a tu honra y suya. Y esto te lo prometo. Por tanto, no mires a lo que pueden decir, sino a lo que te toca, digo, a tu provecho».

¿Cuál es esa promesa de «honra» del arcipreste que aun desde el presente narrativo se proyecta hacia el futuro? Si la palabra servicio alude al tributo, la obra podría ser leída como la respuesta al requerimiento de pago del servicio, por tanto, como una justificación ${ }^{71}$. Lázaro responde a Vuestra Merced ofreciendo un "pobre servicio", el pago reducido (sisado) del impuesto, y se justifica con una biografía marcada por el mal ejemplo de quienes roban, extorsionan, engañan, especulan, infringen la ley y convierten la exención en motivo de honra. Él es sólo uno más. En este sentido, se mantiene un ritmo creciente sobre un mismo tema que alcanza el cenit en «el caso» del amancebamiento. Una culminación genial porque, efectivamente, eso es lo "nunca oído ni visto»: y es que Lázaro aduce como motivo último para justificar el impago del servicio su calidad de sirviente del arcipreste, cuando su relación «laboral» es el amancebamiento. Este sería el verdadero escándalo para el lector común: que el amancebamiento, perseguido e ilegal, se ofrezca como testimonio de la relación señor-vasallo entre el arcipreste y Lázaro. La degradación moral ha llegado a lo más alto.

Sin duda el objetivo del relato es la sátira erasmista, una denuncia de la proliferación de conductas inmorales en un estrato muy concreto de la sociedad; pero el vehículo elegido para llegar al lector «que no ahondare tanto»

71. Los especialistas ya precisaron que formalmente divergía del género epistolar. Véase, por ejemplo, Víctor García de la Concha, op. cit., p. 47-70; Francisco Rico, op. cit., p. 73-92. García de la Concha considera que la declaración puede enmarcarse dentro de los procesos de pesquisas que los obispos emprendían para esclarecer la moralidad de los eclesiásticos (p. 27-32); también defiende esta interpretación Rosa Navarro, que ve detrás de la figura del arcipreste una indudable alusión al confesor real, Francisco García de Loaysa, enemigo de Alfonso de Valdés. Sin embargo, este estudio fiscal nos induce a discrepar de la interpretación estructural de la obra como pesquisa eclesiástica, lo que a nuestro entender no entra necesariamente en desacuerdo con el erasmismo que inspira el Lazarillo, sino con su forma de expresarlo. Se trataría de la respuesta a una pesquisa fiscal, con consecuencias morales particularmente notables. 
es la realidad que estaba a pie de calle ${ }^{72}$. Comprobemos los mecanismos. El primer gran escrutinio sobre la carrera hacia la exención y la trampa fiscal, la Averiguación de 1528 ordenada por Carlos V para solventar los problemas de la recaudación tributaria, se nutre de pesquisas sobre lugares, concejos e individuos que alegaban los más variados motivos para sostener su exención. Ello permite observar cuáles eran los argumentos para la exención más extendidos:

Una vez eximido el núcleo familiar, el siguiente paso fue amparar a los criados y renteros que trabajaban en el patrimonio familiar; de la documentación manejada para todo el siglo XVI cabe inferir la existencia de un doble mecanismo para lograr la exención de tales criados. Uno directo, extendiendo sin más la exención familiar a todos aquellos que se encontraban vinculados laboralmente con dicho núcleo familiar; otro indirecto y con cierta sutilidad jurídica: si la tierra que labraba el criado o rentero era de una persona exenta, todo lo vinculado a la propiedad seguía el mismo régimen jurídico-fiscal del propietario, o bien la carga fiscal se entendía que correspondía al propietario [...]. Esta causa explica la enorme cantidad de exenciones de pecheros detectadas en las jurisdicciones señoriales, singularmente la eclesiástica. [...] Hemos de sospechar que el fenómeno debió adquirir enormes dimensiones (más de 250 casos para el periodo 1532-1535), ya que la mayoría de los pleitos aludían genéricamente al «uso y costumbre». De lo que no me cabe duda es que para los propietarios este mecanismo fue de enorme eficacia para atraer a renteros al ofrecerles como aliciente la exención del servicio ${ }^{73}$.

Sin embargo, en lo que a nuestra hipótesis afecta, hay que puntualizar que el servicio de cortes era recaudado por los oficiales del concejo de cada ciudad:

Aunque los sistemas de repartimiento y recaudación de los servicios de Cortes estuvieron teóricamente reglados desde las instancias superiores de la administración hacendística castellana (Contaduría Mayor de Cuentas y Escribanía Mayor de Rentas), en la práctica el peso de la gestión recaudadora directa sobre las pecherías recayó en el ámbito competencial de los concejos; esto es, de los grupos sociales que dominaban las instituciones locales [...] pudieron obrar a su más completo albedrío, logrando la exención total o parcial para ellas

72. Es significativo que en las en las Cortes de Valladolid de 1544 se pidiese al rey que interviniera ante diversas situaciones que «tocan al estado eclesiastico y a la deshorden y desolucion que ay entre las personas eclesiasticas, especial entre los que tienen exenciones».

73. Juan Manuel Carretero Zamora, «Las oligarquías...», op. cit., p. 19 y 20. 
mismas, sus parentelas, sus clientelas... e incluso, buscando la paz social y la adhesión de sus vecinos, de las localidades donde residían y ejercían los poderes político y social ${ }^{74}$.

Por tanto, para el lector sería coherente que Lázaro, amparado por la oligarquía toledana, hubiera eludido el pago en primera instancia, pero ante la denuncia de las "malas lenguas», o debido a la necesidad y la premura con que la corona estaba reclamando fondos, él mismo o el arcipreste habrían llamado a intervenir en el asunto a Vuestra Merced, un alto cargo de la Real Hacienda. Por eso Lázaro expone la baza de su amistad y le recuerda que existe una promesa de por medio. Con la narración de su vida pretende que Vuestra Merced, sensible al esfuerzo de los que saben subir desde lo más bajo (como significativamente dice Lázaro dos veces), haga una buena alegación fiscal en su favor ante la Hacienda.

Incluso la rotulación de los capítulos narrativos en forma de «tratados» induce a pensar en una declaración por pesquisa fiscal, aun cuando no hubiese sido establecida originalmente por el autor sino con posterioridad (según Francisco Rico) ${ }^{75}$ por parte de unos editores que habrían advertido el cariz del relato y habrían redondeado así el sentido jurídico de la argumentación del pregonero. Formulación que, por otro lado, encajaría con la incisiva idea de que quien habla es un desdentado, pues Lázaro había recibido del ciego «un jarrazo tan grande, que los pedazos de él se me metieron por la cara, y me quebró los dientes». La escena es algo más que un incidente cómico. La dureza de la imagen perdura en la memoria del lector, sobre todo porque el pregonero recalca: «sin los cuales hasta hoy día me quedé», frase por lo demás obvia. Si todo el relato sale de una boca desdentada, el lector contemporáneo podía entrever en él la figura del perjuro: cierta ley revela que, hasta muy tarde (1566), se mantuvo el castigo de pena pública para los falsos testigos, y que esta consistía en extraer los dientes ${ }^{76}$.

74. Juan Manuel Carretero Zamora, «Las oligarquías locales y los mecanismos de exención del servicio de Cortes en la época de Carlos V», en Espacio, Tiempo y Forma, Serie IV, Historia Moderna, $\mathrm{n}^{\circ} 11,1998$, p. 11 y 12.

75. Francisco Rico, op. cit., cap. VIII, p. 113 y ss.

76. TOMO V. LIBRO XII. TÍTULO VI. De los perjuros.

LEY V. D. Felipe II, en Madrid por pragm. de 3 de Mayo de 1566, Conmutacion de la pena de los testigos falsos en la de vergüenza pública y servicio de galeras:

Mandamos, que los testigos falsos en el caso que, segun las leyes de nuestros Reynos, en las causas civiles habian de ser condenados á quitar los dientes, les sea esta pena conmutada en vergüenza pública y servicio de galeras por diez años; y que los dichos testigos falsos en las causas criminales, no siendo caso de muerte, en que se hubiese de executar en él la misma pena, sean condenados en vergüenza pública y perpetuamente á galeras: lo qual se entienda 
Aldo Ruffinatto, contrario a la idea de un Vuestra Merced «ávido gustador de burlas» y de un Lázaro inculpándose enmarañado en su simpleza, señalaba la capacidad de delación ${ }^{77}$ que demuestra el pregonero a lo largo de toda la obra. Nuestra hipótesis es que el objetivo de dicha delación no es exculparse ante una pesquisa eclesiástica (no presenta ningún argumento que le excuse del amancebamiento, y sí, por el contrario, muchos del fraude amparándose en los ejemplos de su entorno), sino ofrecer una declaración que le justifique fiscalmente, y que en su desvergüenza expone el amancebamiento como un alegato más que ha de exentarle y paradójicamente favorecer su carrera hacia la «bonhomía» de una sociedad profundamente inmoral, que confunde honra con privilegio. El hecho de que se esfuerce en recordar en todo momento lo mucho que ha sabido callar y que puede pregonar actúa como amenaza soterrada en su potente declaración.

\section{LOS CUADERNOS DE CORTES}

De la importancia del servicio dan cuenta los cuadernos de Cortes, convocadas por el rey principalmente para el otorgamiento de este impuesto fundamental para las labores de la corona. Hoy es preciso recordar el peso determinante que tuvo el servicio en las relaciones del monarca con los tres brazos estamentales, y su carácter de elemento conflictivo especialmente antes de 1538, año en que el emperador lanzó su célebre «éstas no son Cortes» ${ }^{78}$ y dejó de convocar a la nobleza y el clero por su oposición en materia fiscal.

Obviamente no existen en el Lazarillo alusiones claras a la historia económica, por lo que el propósito de las siguientes reflexiones no es conducir este estudio hacia ninguna fecha concreta, ni siquiera excluyente. Sí lo es, en cambio, proporcionar información sobre el periodo más probable de gestación de la novela a partir de los hechos que estaban teniendo lugar en el reino de Castilla. Ya hemos visto que entre 1528 y 1532 empezaron a recibirse en la Contaduría Mayor los informes de los pesquisidores enviados a realizar las averiguaciones para el reparto del servicio; la lectura de los cuadernos de Cortes permite observar también una importante concentración

\footnotetext{
y extienda á las personas que induxeren á los dichos testigos falsos, siendo de qualidad que puedan ser condenados al dicho servicio de galeras. (ley 7. tit. 17..lib. 8. R.)

77. Aldo Ruffinatto, La vida de Lazarillo de Tormes: $Y$ de sus fortunas y adversidades, Madrid, Castalia, 2001, p. 82-86.

78. Prudencio de Sandoval, op. cit., Libro XXIV, año 1538, cap. VIII. [En línea:] <http:// www.cervantesvirtual.com/servlet/SirveObras/90904584878552620270479/index.htm> (Consulta: mayo de 2008).
} 
de conflictos sociales en torno a los primeros años del imperio, situación que podría haber generado el reflejo fiscal que se vislumbra en la obra.

Las primeras Cortes reunidas por Carlos V, las de Valladolid en 1518, fueron las más acaloradas: se pidió que jurase el rey antes de ser jurado y se transmitió el disgusto del pueblo por la actitud y el séquito del rey. Las crónicas discrepan sobre la cuantía del servicio (150 cuentos o 600.000 maravedís), pero unánimemente declaran que debía distribuirse y cobrarse en tres ańos. Los procuradores o representantes de las ciudades consiguieron que el rey prometiese no hacer otro servicio antes de ese periodo y no imponer nuevos tributos, pero como Carlos iba a ser coronado emperador en Aquisgrán, convocó cortes en Santiago en 1520 para recaudar lo necesario para sus gastos.

En las Cortes de Santiago y La Coruña de 1520 fue cuestión principal si el otorgamiento del servicio debía anteponerse o posponerse al despacho de las cuestiones del reino. Los procuradores de Salamanca se negaron a prestar juramento si antes no se accedía a una serie de peticiones, entre ellas que las cortes no sirvieran para pedir servicio alguno. Los de Toledo, Sevilla, Córdoba, Toro, Zamora y Ávila los secundaron. Carlos V utilizó la división en bandos de los procuradores de Toledo para intentar desbaratarlos, y no admitió a los de Salamanca; las tensiones provocaron una abrupta interrupción y se prosiguió en La Coruña, donde las ciudades de Córdoba y León también pidieron revisar memoriales y capítulos antes de otorgar el servicio. El gran Canciller se negó a aplicar tal novedad, y finalmente sólo siete ciudades y dos villas otorgaron al rey la dudosa victoria de un servicio de 200 cuentos. La imposición de la voluntad real prendió la mecha de la guerra de las Comunidades (1520-1521).

Terminada la guerra se celebraron Cortes en Valladolid en 1523. No había vencido el plazo de los tres años que debía durar el servicio ordinario otorgado en las anteriores. De nuevo solicitaron los representantes del pueblo ser "cumplidamente oídos, despachados sus negocios y remediados los agravios de que se quejaban» antes de entregar el servicio, a lo cual se negó el emperador. Ante la insistencia de los procuradores, consta que el rey mostró su enojo y que el canciller Gattinara censuró su actitud. Finalmente se concedieron 400.000 ducados por tres años. También hubo una significativa petición de los procuradores: que se observaran las leyes y pragmáticas para que los oficios públicos de alcaldías, regimientos, alguacilazgos y otros fueran a manos de personas honradas,

porque de poco tiempo a esta parte ha habido muy gran desorden [...] se han dado a personas que no tienen edad, ni honra, ni reputación en los pueblos [...] de mala vida y ejemplo, y de malas costumbres, 
y de quien todo el pueblo tiene que decir y murmurar, e los otros regidores tienen vergüenza e confusión de ver semejantes personas en su compañía ${ }^{79}$.

También se pidió al emperador que el servicio se repartiese por igual en todo el reino, sin diferencias entre lugares de realengo o de seńorío.

Aunque se había advertido al rey que su reino estaba mucho más fatigado y pobre que en tiempos de los Reyes Católicos, al cabo de dos años Carlos V convocó las Cortes de Toledo de 1525: necesitaba dinero para continuar la guerra en Italia con Francisco I de Francia. Juan Dantisco, embajador de Segismundo I ante el emperador, escribía desde Madrid el 7 de febrero de 1525: «Nunca vi tan pobre la corte como ahora. Se reúne dinero por medios nunca vistos y todo se envía al ejército de Italia» ${ }^{80}$. El anterior servicio de 400.000 ducados no se había terminado de pagar, por lo que se produjo una circunstancia grave y excepcional: se juntaron el anterior servicio y el extraordinario. Se pagaron ambos a un tiempo durante un ańo, situación de la que no existían precedentes. Los procuradores insistieron en que no se demandase otro servicio, que se perpetuasen los encabezamientos de las alcabalas y tercias sin admitir pujas, que se igualasen las vecindades de los reinos para repartir mejor el servicio, que se limitase el número de las personas exentas y que no se diesen a los arrendadores de las rentas reales jueces de comisión, que extorsionaban al pueblo.

Poco más de dos años después, Carlos $V$ tuvo que hacer frente a la amenaza turca que asolaba el este de Europa y a la desconcertante alianza de Francisco I con Roma. Halló la resistencia del clero y la nobleza para la entrega de un nuevo servicio, por lo que sólo

Quedaba el pueblo llano, el pueblo pechero, en definitiva, el que solía pagar los servicios votados por las Cortes. Y en aquel caso no eran disculpas por uno u otro signo, sino auténtica penuria. $\mathrm{Y}$ de tal modo era así, que los procuradores hicieron ver al Emperador que ni siquiera se había podido pagar el servicio de 400.000 ducados con que se le había servido con motivo de sus bodas, aprobado en las Cortes pasadas de 1525. Y Carlos V hubo de comprenderlo ${ }^{81}$.

79. Cortes de los antiguos Reinos de León y de Castilla, Cap. XXIV, op. cit.

80. José Luis Betrán Moya, «La coyuntura socioeconómica entre 1527 y 1556: de la expansión a la crisis», en Manuscrits, n 16, 1998, p. 17.

81. Manuel Fernández Álvarez, Carlos V, el César y el Hombre, Madrid, Espasa, 1999, p. 360. 
Los tres brazos estamentales, por motivos distintos, se resistieron al unísono a otorgar el servicio que les pedía. Carlos $\mathrm{V}$ mandó deshacer las cortes. Por eso

A partir de las Cortes de Toledo de 1525 Carlos I había mandado algunos representantes suyos a las ciudades, provincias y partidos de sus reinos, para saber cómo los Concejos se sentían cargados y agraviados con los servicios que se estaban pagando, y así los que se hicieran en adelante estuvieran repartidos más justamente. A la vista de la información conseguida, y después de tratar el asunto con el Consejo y con los Contadores mayores, el rey había dispuesto que el pago de los servicios posteriores se hiciera de una forma muy concreta. En las cartas de receptoría que recibieran las ciudades enviadas desde la Corte ya se encontraría diferenciado lo que tenía que pagar cada ciudad y sus arrabales [...] en las ciudades tenían que juntarse el Corregidor o el Juez de residencia con las personas designadas por los pecheros para distribuir el servicio entre los vecinos pecheros, sin eximir a ninguno [...] Una vez realizado el reparto se comunicaría a los Receptores del partido y éstos a los Contadores mayores del rey ${ }^{82}$.

Es significativo que en las siguientes Cortes de Madrid, en 1528, los procuradores pidieran que el servicio otorgado (200 cuentos de maravedís) se emplease únicamente en la defensa del reino: expresaban así una velada censura hacia la política exterior. Volvió a encomendarse la cobranza de los servicios a los procuradores y a denunciarse el abuso de los arrendadores, y se solicitó que la soldadesca se alojase por igual en lugares de señorío que de realengo, para repartir su carga.

Cronistas e historiadores coinciden en la docilidad con que en adelante los tres brazos estamentales acatarían las imposiciones de la corona. Sí hubo reclamaciones, reivindicaciones para que se aplicaran las leyes que no se ponían en práctica, discusiones sobre el encabezamiento y la sisa, y muy relevantes por cierto; pero no se volvió a desafiar la autoridad real, y la impresión general que arrojan los cuadernos de Cortes y las crónicas es que estas cuestiones se lidiaron entre quienes tenían competencias para ello, sin alcanzar la dimensión social que habían tenido en tiempos anteriores (concretamente en torno al estallido de la guerra de las Comunidades). El pueblo de Castilla aceptó resignadamente su destino.

82. María del Pilar Esteves Santamaría, «Toledo en las Cortes de Carlos I: cuestiones de interés general para el Reino", op. cit., p. 235. La autora precisa que esta provisión fue dada por Carlos I en Valladolid en 1532 pasando posteriormente a formar parte de la Nueva Recopilación, Tomo VI, Libro XIV, Ley IV. 
Por otro lado, si nos atenemos al segundo impuesto más importante, la alcabala, también revela un periodo de crecimiento más intenso en las primeras décadas del siglo XVI. El primer encabezamiento general de alcabalas, que aliviaría la presión fiscal de los municipios, no tuvo lugar hasta 1536, año que los economistas toman como referente de un cambio de periodo económico. La alcabala sobre géneros vendidos o permutados había experimentado una fluctuación importante: en las Cortes de Burgos de 1393 se había fijado en un $3 \%$, los Reyes Católicos la elevaron al $10 \%$ a partir de 1491 y tras las Cortes de Madrid de 1539 fue rebajada de nuevo a su valor primitivo, por lo que el periodo de máxima presión se sitúa en los casi cincuenta años que van de 1491 a 1539 . Aunque Isabel la Católica había ordenado en su codicilio de 1504 el encabezamiento de las alcabalas "para que se cobrasen sin vejación ni fatiga», los procuradores tuvieron que pedir en las cortes de 1515, 1518, 1520, 1523 y 1525 que los contadores no admitiesen pujas, y en caso contrario se anulasen. Pero aunque así se acordó no se cumplió, creció la renta y el rigor de los arrendadores ${ }^{83}$. Era tan grande el miedo que tenían los concejos y particulares de las penas, que se resignaban a pagar mayor cantidad de la que debían.

A partir del encabezamiento de las alcabalas, gestionadas por los procuradores de las ciudades y con un pago seccionado en tercios o trimestres, la alcabala se convirtió, en opinión de Ramón Carande, en un servicio más. Por otro lado, a partir de la segunda mitad del siglo XVI nobles e hidalgos fueron ocupando progresivamente los cargos concejiles de las ciudades y villas de realengo a través de dos vías: una la institucional, que había dividido a los regidores de los Ayuntamientos por mitad, y otra la compra de oficios, enajenados en masa por los Austrias ${ }^{84}$, por lo que el nuevo equilibrio de poderes iría eliminando las diferencias de privilegio entre lugares de señorío y de realengo ${ }^{85}$.

83. Cortes de los antiguos Reinos de León y de Castilla, Cap. XXIV, op. cit.

84. Javier María Donézar Díez de Ulzurrun, «Los decretos de la Real Hacienda de 1749, los poderes locales y la representación del reino", en Espacio, Tiempo y Forma, Serie IV, n ${ }^{\circ} 12$, 1999, p. 297-320.

85. Una nueva realidad que difiere del escenario que envuelve el Lazarillo, lo que no impide que Quevedo, en el Buscón (escrito en la primera década del s. XVII), realice juegos de palabras con las diversas acepciones de la palabra servicio y que describa las prácticas cambistas de algunos mercaderes, además de utilizar significativamente el apellido Zúńiga; lo cual delata, en nuestra opinión, una lectura económica de la obra referencial de la picaresca. 
